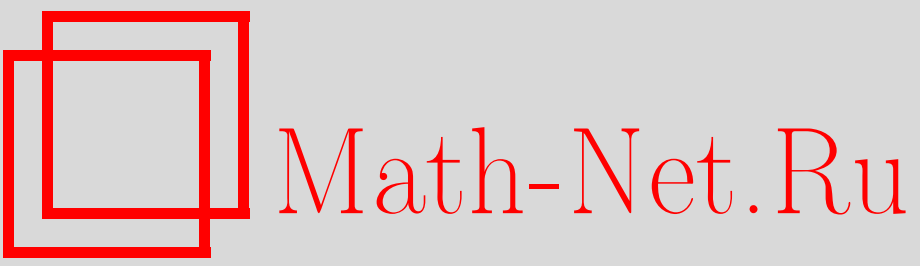

Информация о девятой Колмогоровской студенческой олимпиаде по теории вероятностей, Теория вероятн. и ее примен., 2010, том 55, выпуск 2, 412-414

DOI: https://doi.org/10.4213/tvp4227

Использование Общероссийского математического портала Math-Net.Ru подразумевает, что вы прочитали и согласны с пользовательским соглашением

http://www.mathnet.ru/rus/agreement

Параметры загрузки:

IP: 54.174 .149 .18

26 апреля 2023 г., 17:15:18 


\section{ИНФОРМАЦИЯ О ДЕВЯТОЙ КОЛМОГОРОВСКОЙ СТУДЕНЧЕСКОЙ ОЛИМПИАДЕ ПО ТЕОРИИ ВЕРОЯТНОСТЕЙ}

В ознаменование дня рождения А.Н. Колмогорова кафедра теории вероятностей механико-математического факультета Московского государственного университета им. М.В.Ломоносова при поддержке Московской государственной академии тонкой химической технологии им. М.В.Ломоносова провела девятую Колмогоровскую студенческую олимпиаду по теории вероятностей. Информация о предыдущих олимпиадах содержится на сайте кафедры теории вероятностей (http://mech.math.msu.su/probab) и в предыдущих выпусках журнала.

Олимпиада была проведена 17 апреля 2010 г. раздельно для I-II и III-V курсов (продолжительность - 4 часа). В олимпиаде приняли участие 35 студентов I-II курсов и 29 студентов III-V курсов механико-математического факультета и факультета ВМиК Московского государственного университета, а также механикоматематического факультета Киевского национального университета, математикомеханического факультета Санкт-Петербургского государственного университета, факультета управления и прикладной математики Московского физико-технического института.

\section{Предлагавшиеся на олимпиаде задачи}

В скобках после номера задачи указываются курсы, на которых предлагалась данная задача, затем число решивших ее студентов I-II курсов и, наконец, число решивших ее студентов III-V курсов (для задач, которые предлагались только в одной возрастной категории, приведено только число решивших).

Задача 1. (I-V; 3,15$)$ Случайная величина $X$ распределена по закону Пуассона с параметром $\lambda>0$. Доказать, что $\mathbf{P}(X>a) \leqslant e^{-\lambda g(a / \lambda)}$ для $a>\lambda$, здесь $g(x)=$ $1-x+x \ln x$.

Задача 2. (I-V; 10, 14) Случайные величины $X_{1}, X_{2}, \ldots$ независимы, одинаково распределены и принимают только целочисленные значения, причем $0<\mathbf{P}\left(X_{1}\right.$ делится на 3$)<1$. Пусть $S_{n}=X_{1}+\cdots+X_{n}, n \in \mathbf{N}$. Доказать, что существует $\lim _{n \rightarrow \infty} \mathbf{P}\left(S_{n}\right.$ делится на 3$)$, и найти его.

Задача 3. (I-V; 0, 0) Случайные величины $X$ и $Y$ имеют стандартное нормальное распределение и независимы, а функция $f: \mathbf{R} \rightarrow \mathbf{R}$ гладкая, выпуклая и неотрицательная. Доказать неравенство $\operatorname{cov}(f(X+Y) X, f(X+Y) Y) \geq 0$ (предполагается, что данная ковариация существует).

Задача 4. (I-V; 0, 1) Пусть случайная величина $X$ имеет конечную дисперсию и $h(x)=\min (|x|, 1) \operatorname{sign}(x)$. Верно ли, что $\mathbf{D} h(X) \leq \mathbf{D} X$ ?

Задача 5. а) (I-II; 3) Пусть $X$ и $Y$ - квадратично-интегрируемые случайные величины на одном вероятностном пространстве, причем $X$ принимает конечное число значений. Найти функцию $f: \mathbf{R} \rightarrow \mathbf{R}_{+}$, на которой достигается $\min \mathbf{E}(f(X)-Y)^{2}$ по всем неотрицательным $f$.

б) (III-V; 5) Тот же вопрос, но не предполагается конечность множества значений $X$, а минимум берется по всем неотрицательным борелевским $f$, для которых $\mathbf{E} f^{2}(X)<\infty$. 
Задача 6. (I-V; 4, 1) В ящике лежат 1 белый и 99 черных шаров. Не глядя достанем каждой рукой по одному шару и тот шар, который оказался в левой руке, перекрасим в цвет шара в правой, а затем вернем шары назад. Найти математическое ожидание минимального числа таких действий, после которого все шары в ящике станут одного цвета.

Задача 7. (I-V; 0,2$)$ Случайная величина $X$ неотрицательна и не зависит от величины $Y \sim N(0,1)$, а их произведение распределено по Лапласу (разность двух независимых показательных с параметром $\lambda>0$; его плотность имеет вид $\lambda e^{-\lambda|x|} / 2$, число $\lambda$ известно). Найти плотность $X$.

Задача 8. (I-V; 1,0$)$ Пусть на плоскости задано пуассоновское поле точек интенсивности $\lambda>0$ (т.е. случайно разбросаны точки так, что если ограниченные борелевские множества $B_{1}, \ldots, B_{n}$ попарно не пересекаются, то числа точек в них независимы и имеют распределение Пуассона с параметрами $\lambda \mu\left(B_{1}\right), \ldots, \lambda \mu\left(B_{n}\right)$ соответственно; $\mu$ - мера Лебега). Каждую точку $x \in \mathbf{Z}^{2}$ соединим отрезком с ближайшей к ней точкой пуассоновского поля. Найти математическое ожидание суммарной длины всех частей таких отрезков, находящихся внутри квадрата $[0,1]^{2}$.

Задача 9. (I-V; 1,11$)$ Пусть случайная величина $X$, имеющая непрерывную плотность, сосредоточена на отрезке $[0, \pi]$, и распределения случайных величин $\cos X$ и $\cos 2 X$ совпадают. Доказать, что распределение $X$ - равномерное на $[0, \pi]$.

Задача 10. (III-V; 1 ) Случайные величины $X_{1}, X_{2}, \ldots, X_{n}$ независимы и одинаково распределены, а $F$ - функция распределения. Построить какой-нибудь критерий для проверки гипотезы, что величины $X_{i}$ имеют функцию распределения $F$ (против альтернативы, что их функция распределения не такая), мощность которого при любой альтернативе стремится к 1 (при $n \rightarrow \infty$ ).

\section{Победители олимпиады}

Разбор задач и награждение победителей проводились на Большом семинаре кафедры теории вероятностей 21 апреля 2010 г.

\section{Победители среди студентов I-II курсов \\ Первая премия}

Шульчевский Дмитрий Игоревич - студент II курса механико-математического факультета Московского государственного университета.

\section{Вторая премия}

Воробьев Илья Викторович - студент II курса механико-математического факультета Московского государственного университета.

Калачев Глеб Вячеславович - студент II курса механико-математического факультета Московского государственного университета.

Токмаков Петр Сергеевич - студент II курса механико-математического факультета Московского государственного университета.

Третья премия не присуждена.

\section{Победители среди студентов III-V курсов Первая премия}

Шамов Александр Александрович - студент III курса механико-математического факультета Киевского национального университета (научный руководитель А. А. Дороговцев).

\section{Вторая премия}

Тропин Николай Владимирович - студент IV курса математико-механического факультета Санкт-Петербургского государственного университета (научный руководитель - М. И. Гордин). 


\section{Третья премия}

Гимадеев Ренат Айратович - студент V курса факультета управления и прикладной математики Московского физико-технического института (научный руководитель - М. Н. Вялый).

Подхалюзин Александр Викторович - студент V курса математико-механического факультета Санкт-Петербургского государственного университета (научный руководитель - Я. Ю. Никитин).

Тюрин Илья Сергеевич - студент V курса механико-математического факультета Московского государственного университета (научный руководитель А. В. Булинский).

27 апреля 2010 2.

Оргкомитет девятой

Колмогоровской студенческой олимпиады

по теории вероятностей:

член-корреспондент РАН, профессор А. Н. Ширяев,

к.ф.-м.н., дочент А.П. Шашкин,

к. ..-м.н., ассистенты Е. Е. Баштова, М. М. Мусин,

Е. М. Суханова, Д. А. Шабанов,

ассистенты А. Т. Абакирова, И. Г. Эрлих, П. А. Яськов, аспиранты О. А. Бутковский, А. А. Каменов, Д. А. Ярцева. 